\title{
The challenges facing English schools in the journey to 2030, with a specific focus on London
}

\author{
David Parry* - Education consultant, UK
}

\begin{abstract}
By the end of the twentieth century, there was concern about the low levels of achievement in many English schools - particularly those in London - and this acted as a catalyst for change, a key remedial initiative being London Challenge. While there is much to celebrate about the improvements that have been made over almost two decades, the next decade presents a number of challenges that will have to be faced if the schools are to continue on their success trajectory to 2030. This article explores some of these challenges. Key must be an education master plan, particularly because of the uncertainties resulting from Brexit.
\end{abstract}

Keywords: London; England; challenge; improvement; Brexit

\section{Introduction}

I undertook my teacher training in London in the mid-1970s and have taught in the capital for 20 years, most recently as the head teacher of a large comprehensive school teaching 11-18-year-olds in East London. My experience tells me that schools have improved immeasurably since I started working in them in the 1970s, and that the most dramatic improvement has been made over the course of this century so far, through a momentum of self-improvement that has generated a pride in London's educational provision. In turn, this has boosted the system's morale, and the city has acted as a beacon for other English conurbations - for example, Birmingham, Manchester and the Black Country - as well as for schools elsewhere. Education in London is now world class. According to the Department for Education (DfE, 2018b), girls and boys leaving inner London primary schools in 2018 outperformed all other children in England in their standard attainment tests (SATs), which assess skills in reading, writing and maths. In London as a whole, 70 per cent of all children passed these tests, compared with a national average of 65 per cent. This is an increase for London of 4 per cent compared with 2017. What has been achieved in London is remarkable, but as the capital city and England approach the century's third decade, it is timely to look at how the improvements made thus far can be built upon in the context of a number of challenges that the education system faces - many of these not unique to London but being pertinent to other parts of England as well.

This article begins by looking at the improvements in London schools since the start of this century, before an evaluation of the opportunities for London for 2030. There is then an exploration of the educational challenges and stresses that London and England will have to face and overcome if its schools are to be successful in 2030. The article does not include the other constituents of the United Kingdom (Northern Ireland, Scotland and Wales), as they have devolved governments. 


\section{The London success story}

In 1997, the UK elected a new Labour Government, by which time the poor performance of London schools had been highlighted in the press for some time (Brighouse, 2015). There was a much higher percentage of students attending private schools than nationally, and in terms of attainment the schools were outperformed by those in the rest of England (Woods, 2014). Labour's first major policy programme to tackle urban educational underachievement was not aimed at London alone. Called the Excellence in Cities (EiC) programme, and launched in 2000, it was devised to improve examination results and deal with student dissatisfaction. It was the London Challenge, launched by the Secretary of State for Education, Estelle Morris, in 2003 that was the first London-specific policy 'to address systematic underperformance in the capital's schools' (Berwick and John, 2017: 60). Its first chief adviser was Sir Tim Brighouse, who was also the Schools' Commissioner for London from 2002 to 2007. In schools involved in London Challenge that were deemed be failing, and were a priority as 'Keys to Success Schools', there was an improvement of 7 per cent in the number of $A^{*}$ to $C$ grades, including English and maths, compared with the national improvement rate of 2.5 per cent; and the number of schools in special measures fell from 17 in 2003 to 3 in 2010 (Woods, 2014).

However, Blanden et al. (2015) found that the performance of disadvantaged students in London had begun to make substantial improvements from the mid-1990s onwards - in other words, during the previous Conservative Government and before Labour's initiatives. They are not alone in questioning whether the improvements made in examination results can be attributed solely to London Challenge (Kidson and Norris, 2014; Burgess, 2014). The influence of Brighouse and London Challenge was not just across the 32 London boroughs but affected other parts of England as well - what has been called the 'London effect'. Here again, however, there is contention: 'there is doubt about its exact nature and little agreement about its potential causes' (Hayes et al., 2018: 491).

London Challenge came to an official end in 2011 and, with its demise, the concern was whether the moral drive for improvement alone can sustain a highperformance system' (Husbands, 2014: 146). The legacy of London Challenge today may be found in the London Leadership Strategy (LLS, 2018), intended to 'keep its spirit and mission alive'. In 2009, the LLS established a Going for Great (G4G) programme for schools that, in Ofsted's terms, were deemed to be outstanding. One of the major aims of G4G is 'to encapsulate the key features and qualities of schools which are consistently outstanding in order to better understand how outstanding schools become great schools' (Woods and Macfarlane, 2017: 83). G4G exudes the joie de vivre of collaboration: it assumes great ambition for London schools and beyond.

\section{Optimism for London and its schools in 2030}

'So, London 2030: what shines through is the spirit of the Olympics - London leading the nation and the best in the world, a spirit of unity, urgency and change' (Adonis, 2014). A key legacy of the 2012 London Olympics is not just sport: it has stimulated a growth in education to the east of the city, with Stratford Science City hosting extensions of University College London (UCL) and new campuses for Imperial College and Queen Mary University. Free schools such as School 21 have opened in the area. Adonis (2014) quotes Newsweek when they cite London as their 2030 Capital of the World: 'when people from all over the world think of a land of opportunity, they no longer think of 
the Statue of Liberty but of Big Ben'. In addition, Edtech UK (2015: 3) is 'looking to do its part to make London and the UK a major education technology hub for the world'. London is 'a learning technology epicentre' (Busson, 2018: 79). The population of London in 2018 was estimated to be 8.85 million (Population UK, 2019) and there is a growth forecast for it to reach 10 million by 2030 (Smartrail World, 2015). There are major infrastructure projects such as Crossrail 2, HS2, east-west rail and Thames Estuary 2050, which also fuel the optimism. But London cannot be complacent: other European cities covet the crown. Schools in London have improved dramatically so far this century, but this trajectory cannot be guaranteed, and there is a poignancy in the maxim 'good is the enemy of great' (Collins, 2001: 1).

The key unknown when exploring any element of London's, or England's, future is its future within Europe.

\section{London in the post-Brexit world}

The decision of the British electorate in the June 2016 referendum to leave the European Union (EU) was dubbed 'Brexit', and the negotiations to sever membership of the EU became a political quagmire. 'Brexit' became a synonym for confusion and complexity, with highly polarized views as to the implications for London, once the UK had left the EU: London would either wither as one of the world's leading financial and economic centres, or it would be liberated from the fiscal constraints of the EU and become an even stronger financial centre. Clearly, whatever happens in London will affect the rest of the UK, but this article is concerned with looking at London's and England's education system in the 2020s: schooling in a post-Brexit context. It will also explore five other challenges not directly connected to, or attributable to, Brexit. These five challenges are considered by the author to be the most major, and are not covered in any order of severity or significance.

While not necessarily linked to Brexit, London faces the challenge of having its power and influence dissipated to the English regions. There may be a scenario where there is a rebalancing in England to address the biases towards London and the South-East. This could manifest itself in devolved powers to the regions, with boards being able to set attractive business taxes. The danger here, for London, is that as businesses and their workers move away from the conurbation, it becomes what a report by Cambridge Econometrics and SOW (Policy Institute at King's, 2017) call a 'Paris-on-Thames', where there are still visitors in abundance but the city is a 'less economically dynamic centre, surrounded by struggling suburbs' (ibid.: 28); or, like Rome, 'Still a very important city, with a great history to draw on, but one with a public infrastructure that is fraying and a place in the global economy which is under pressure' (ibid.: 30).

The fragility of London is such that we need a master plan for education for the next decade. The city had one after the Great Fire of 1666, which rendered 20 per cent of Londoners homeless, and after the Blitz of the Second World War. The postBrexit world is a major challenge, which means that we must plan for the future, and plan on a scale unprecedented since 1945. Philip Hammond, the Chancellor of the Exchequer, announced in his 29 October 2018 Budget that austerity was coming to an end; but schools have suffered spending cuts since austerity began after the financial crash of 2008, and there is little evidence of there being any significant increase in funding in real terms over the foreseeable future. The challenges for London's and England's schools over the next ten years have therefore to be seen through the prism of Brexit and financial constraints. As these challenges are also pertinent to the rest of 
England, it could be argued that the master plan should also include England - or be two separate plans: one for London and one for England.

\section{Challenge one: Shortage of high-quality teachers}

While historically London has always faced the challenge of a shortage of high-calibre teachers, the current dearth is not just confined to the capital. The situation was made even more severe at the turn of the century, with lurid coverage in the press of classrooms that were out of control. However, more recently, some schools have adopted a 'zero-tolerance' approach to school discipline with the introduction of severe sanctions for students who do not conform to the strict behavioural codes, with, for example, silent corridors and isolation booths. This might make the teaching profession more attractive, as teachers will know that there will be a consistent approach to dealing with disruptive behaviour. However, there is not a consensus that discipline in schools is less of a problem than it used to be. While acknowledging that there have been improvements in behaviour since the guidance for teachers on behaviour and discipline (DfE, 2011a) was published, Joanna Williams (2018: 6) of the right-wing think tank Policy Exchange, in a paper entitled 'It just grinds you down', says that disruptive behaviour is still a major problem in English schools and has a 'negative impact' on both teacher recruitment and retention.

The seemingly perennial issue of a shortage of teachers in London might be helped if, as suggested by Leibreich (2017), there is increased investment in public transport to free up spaces currently occupied by parked cars for houses and parks. At present, we are only building a third of the new homes that London requires: we need an additional 40,000 a year (Adonis, 2014). In 17 of the London boroughs, the average rent is more than half the average wage (ibid.). There are also environmental disincentives to working in the capital, with great concern about the quality of air (Londonair, 2018). The capital can also tempt maths and physics teachers away from education to work in the City, where jobs can start at $£ 50,000$ a year. London has always relied on overseas teachers to alleviate the shortage of UK-trained teachers. A binary perspective on the next decade sees either the rise of Trump-style protectionism in the UK - particularly in a post-Brexit epoch - or a more liberal approach to the international migration of teachers from abroad. London schools desperately need the latter.

The House of Commons Committee of Public Accounts (2018a) chastised the DfE for spending too much on training new teachers ( $f 550$ million), rather than retaining existing ones ( $£ 36$ million). The response from the DfE (2019c) has been to produce a strategy document on the recruitment and retention of teachers. There is a clear emphasis on the latter, and an acknowledgement that 'Early career retention is now the biggest challenge that we face' (ibid.: 20). To help address this latter issue, an Early Years Framework is to be introduced: 'a funded 2-year support package for all new teachers, providing them with the support enjoyed by other top professions' (DfE, 2019d: 1). The hope is that this will staunch the haemorrhaging of teachers from the profession after just a few years of service.

The Conservative and Liberal Democrat Coalition Government paper '20102015 government policy: Teaching and school leadership' (UK Government, 2015) overcomplicated the teacher training routes. There was a conscious policy shift away from the domination of universities as teacher trainers through the Postgraduate Certificate in Education (PGCE) to routes such as School Direct, where the school recruits the trainee and the university is a partner. School Direct has two pathways, on one of which the trainee is paid as an unqualified teacher but has to have had three 
years' experience of work. This route might well attract more trainees if this prerequisite was removed. The abolition of tuition fees for the PGCE route might also make this pathway to teaching more attractive for graduates.

At the March 2018 annual conference of the Association of School and College Leaders (ASCL), Damian Hinds (2018), the Secretary of State for Education, announced that it was government policy to work to reduce the workload burden on schools. For example, he suggested that the length and frequency of school reports could be reduced. Too often, teachers spend too much time reinventing the wheel. In the era before academization, when state schools were controlled by local education authorities, there was much in the sharing of good ideas and resources, often under the guidance of local specialist advisers. However, despite the demise of the local education authorities, there is now evidence of a de-siloing in education, with 'a growing ambition to find ways of emphasising collaboration over competition' (Barton, 2018: 4). The shortage of teachers, and the imperative to maintain a work/life balance, should give impetus to this. While it may be very difficult to gain stakeholder consensus, the reorganizing of the school year to break up six- or seven-week half terms into less onerous one-month sessions has the potential to reduce teacher workload and stress, as well as that of students. Such a move would almost inevitably mean the end of the long summer break, considered by many teachers as sacrosanct and a 'perk' of the job.

Due to the heavy workload of teachers and reduced budgets, time for continuing professional development (CPD) has 'been squeezed out' (Bubb and Earley, 2013: 246), but could be a daily afternoon occurrence, teachers having been freed up from the conventional teaching days through chat rooms and 'compulsory, personalised online teaching courses' (Rogers, 2016: 2) for students completed the night before. This CPD would be live-streamed, and could be a forum 'where educators from around the world interact, share and collaborate like never before. Problems become much easier to solve with a thousand heads instead of one' (ibid.: 4).

High-quality coaching could help to stop teachers leaving the profession, but it needs to be based on clear evidence of what has worked successfully in schools, rather than hyped-up, transient fads. Harnessing Educational Research, a joint report by the Royal Society and the British Academy (2018), recommends the creation of an Office for Educational Research as a forum to bring together teachers, professional researchers and government researchers to provide teachers with 'more support to use evidence and insights from research to develop their practice and understanding' (ibid.: 10). The expectation is that teachers will be researchers themselves, as part of their professional standards, helping to create a culture where what is known to be effective teaching and learning is shared. Not only would this help to enhance the professional standing of teachers, it would also reduce workload through the sharing of efficacious resources and pedagogical approaches. A school that promotes and supports teacher research, and values in-house responses to it, may find that it helps 'to develop resilience' in the face of the 'hostile environment' (Godfrey, 2016: 313) of accountability.

There has been an emergence of 'performativity' (Ball, 2003: 49), resulting from the 'new public management' (ibid.: 43) born of neo-liberalism, with schools having high levels of accountability as they have morphed into being run more like businesses. This 'performativity' is Foucauldian, with its regular surveillance and monitoring of teachers and their performance in the classroom, and has resulted in 'a culture or a system of terror' (ibid.: 49). New public management and performativity have 'resulted in a hierarchy of pressure vices into school improvement agendas', leaving staff 'drained of the energy and creativity to inspire students' (Parry, 2011: 60). Not all schools have 
succumbed to the neo-liberalism of 'performativity'. Astle (2017: 1) refers to those heads and schools who have refused 'to play this bureaucratic education-by-numbers game', giving them the nomenclature of 'missionaries', as opposed to the 'gamers' those that have succumbed. Examples given of schools in London that are driven by a mission to provide a broad and liberal education, which transcends playing the narrow accountability game of neo-liberalism, include Michaela Community School in Brent, Reach Academy in Feltham and School 21 in Stratford. It can be done.

The high level of scrutiny to which the 'gamers' succumb may be contrasted with the situation in Finland, where 'the absence of imposed control is perceived as a key element to the success' of schools (Busson, 2018: 25). This is trusting the professional. Precey (2012) refers to the importance of trust for leaders and staff in schools, calling it 'the magic glue'. Head teachers should implicitly trust the professional integrity of staff, much like the way in which the head of a law firm trusts their lawyers (Rogers, 2016: 4). Such a shift in the culture of school leadership and management might help to alleviate the problem of teacher recruitment and retention.

\section{Challenge two: The curriculum}

As Secretary of State for Education from 2010 to 2014, Michael Gove instigated changes to the General Certificate of Secondary Education (GCSE) and Advanced (A level) examinations, making them more difficult and largely eliminating the coursework elements in order to place a greater emphasis on terminal examinations. In general parlance, the policy was to make exams more 'academic', but the almost wholesale removal of coursework led to criticism that students, particularly at GCSE level, would feel alienated by the new courses. The UK has a disappointing record with regard to placing vocational qualifications on a par with academic qualifications. The Labour Government of 2005-10 spent almost $£ 324$ million on developing the Diploma to resolve the education apartheid between academic and vocational qualifications, but there was minimal take-up by students and employers, partly due to the complexity of the qualification.

Technical levels (T levels) are being introduced from September 2020. These new qualifications have been designed in conjunction with employers, and are intended to be a technical alternative to A levels. Each T level will provide 'an industry placement of at least 45 days' in their chosen industry or occupation (DfE, 2019b). The first courses are going to be digital, construction and education and education and childcare. The aim is for T levels to eventually replace many of the existing technical and vocational qualifications being studied by technical students. For them not to become a synonym for the disaster of the Diploma, there are three key challenges: (1) recruiting employers who will provide high-quality work placements; (2) providing the training and resources for the teaching outside the work place; and (3) convincing students and all stakeholders of the value of the qualification. Schools in England have never been able to fully integrate apprenticeships into their curriculum. There has been a perception, particularly among students and parents, that they are inferior to established brands such as GCSEs and A levels. However, vocational education may receive a boost if the current review of higher education being chaired by Philip August publishes a proposal to refuse university student loans to students with three $D$ grades or lower at $A$ level. As an alternative pathway, such students would be offered loans for cheaper vocational courses in further education colleges. Such a move might pave a credible and attractive vocational route from Key Stage 4. 
There is a clear capacity issue for London, given its high population and demand for high-quality vocational placements with employers. Both employers and students will need to be convinced that $\mathrm{T}$ levels have credibility and currency. This will be difficult, given the UK's deification of academic qualifications and cynicism about vocational courses. The broadening of the curriculum to embrace vocational courses needs to be a key element in any master plan.

There are grounds for optimism for a liberation of the curriculum from its Ofstedinduced focus on traditional academic subjects. The Chief Inspector of the Office for Standards in Education (Ofsted), Amanda Spielman (2018), admitted that the current Ofsted inspection framework has made the curriculum a 'casualty', by obliging schools to model it to match the English Baccalaureate (EBacc). Ofsted uses the EBacc as one of its accountability measures; it is a combination of subjects considered by the government to be important for young people to study at GCSE level between the ages of 14 and 16. The EBacc includes English language and literature, maths, the sciences, geography or history, and a language. The DfE (2019a) refers to a study by the Sutton Trust that revealed that studying the EBacc could help to improve a young person's performance in English and maths, and to research by UCL Institute of Education that shows that taking the EBacc improves the prospects for proceeding to further education or employment. However, students who are ill-suited to this portfolio of academic, traditional subjects have found themselves having to accept a timetable fitted to it, with more appropriate subjects - possibly vocational - having been removed from their school's curriculum. Many such students have then become disengaged with school and education, and have become more difficult to motivate and to teach, adding further pressure to the lives of teachers. The challenge over the next decade is to remodel the curriculum to broaden the education provided for young people, beyond the EBacc, to facilitate broader student engagement.

Ofsted (2018a) has proposed changes to its inspection framework from September 2019, and one of these changes will be the removal of 'outcomes' as a stand-alone judgement category in reporting, to be replaced by a 'quality of education' category. This is an attempt to reduce the extent to which some schools have narrowed their education provision in order to meet the current Ofsted inspection framework. Spielman (2018) acknowledges that Ofsted has, for some time, not placed enough emphasis on the curriculum: 'We all have to ask ourselves how we have created a situation where second-guessing the test can so often trump the pursuit of real, deep, knowledge and understanding.' There is a strong irony in Spielman's lamentation about the narrowing of the curriculum and the obsession with tests and examinations: they are born of Ofsted itself and its inspection frameworks since it was established in 1992. It has taken over a quarter of a century for there to be an official acknowledgement by Ofsted that operating the curriculum to placate it has resulted in pedagogical and philosophical myopia and paralysis in so many schools. To attempt to find an antidote to this, the challenge for schools is for them to have an in-depth reflection and review of the curriculum that they offer, being fully cognizant that too often schools see the curriculum as a synonym for the timetable. The Labour Party 2017 election manifesto pledged to give teachers more direct involvement in the curriculum. If Ofsted are to look at the 'quality of education', rather than just at outcomes, then that review must include things that go on beyond the timetable including extra-curricular activities. The latter currently often rely on the goodwill and time of staff, rather than on financial remuneration, and the challenge is to maintain and grow this enriching provision in the context of staff well-being and the desire to achieve a work/life balance. 


\section{Challenge three: Students under stress}

Young people today are buffeted by social media. While schools might include internet safety and the dangers of social media as part of their curriculum, there is a limit to the extent to which they can intervene in the cyber-bullying that occurs out of school hours and off the school site, where students risk being exposed to toxicity in their social, virtual lives. It is not just in the virtual world that students can experience stress. The narrowing of the curriculum, and the relentless focus on tests and examinations, have also intensified the pressure on students. A DfE (2018a) paper, Mental Health and Behaviour in Schools, presents a detailed response as to how schools might deal with the increase in the number of young people suffering from mental health problems. It is non-statutory, departmental advice, and talks about how schools 'have a central role in enabling their pupils to be resilient and to support good mental health and wellbeing' (ibid.: 4). It summarizes the role of the school as having four strands of response: prevention, identification, early support and access to specialist support. The challenge for schools lies in the resources required to facilitate the levels of support suggested. The government has acknowledged the seriousness of the issue of the mental health of children, with a pledge of an additional $f 2$ billion a year to help to address it. The aim is to have a trained mental health professional in every school, but this will not be an easy panacea: Ofsted (2018b: 8) reports that there is 'a shortage of specialist mental health provision, and the provision that exists is not distributed evenly around the country'. This problem might be reduced if the government commits to a tenyear spending plan to support mental health in schools, as it might make being a trained mental health professional working in a school a viable career path, possibly encouraging existing teachers to undergo such training.

The curriculum straitjacket needs to be loosened to reduce the stress on students. Not everything needs to be examined and built around assessment objectives. There is high value in students having elements of their timetable that are cathartic and liberating for the soul. Usefully, there appears to be a shift away from Michael Gove's obsessive focus on examinations, with Damian Hinds publishing a 'bucket list' of life goals that primary school children will be encouraged to meet as they move through that phase of their schooling, as part of a greater emphasis on resilience and character building. Examples include learning to climb trees, explore caves and starting a vegetable patch. The work of Martin Seligman at the University of Pennsylvania on positive psychology developed into what has become known as the field of 'positive education'. This pivots on prevention, and involves training teachers to improve their own mental health and resilience, with them then using the skills and knowledge from their own experience of this to help their students.

There is stress for both teachers and students in schools, and over the next decade the challenge is to find the time and the resources to train teachers to help not only themselves, but also their students.

\section{Challenge four: Inequalities and social mobility}

Teach First, a charity launched in 2002, has had success in placing good-quality teachers in schools in low-income areas, in its avowed mission to break the link between low income and low academic achievement, which 'is greater in the UK than almost any other developed nation' (Teach First, 2019c). Teach First (2019c) aims to develop 'great teachers to work in low-income areas' often associated with poor behaviour. Its template has yielded impressive results. By 2018 it had placed ten 
thousand teachers in schools in low-income areas, supporting more than one million students. The mantra of Teach First has acted as Pied Piper, recruiting teachers to work in schools where the low income of students has been used as an excuse for low academic achievement. It posits that the inequality is 'entirely solvable' (Teach First, 2019b), and articulates a clarion call of 'come and join us and make a difference'. There are, however, concerns about teacher retention rates with Teach First, with critics arguing that the problem can be found in the charity's name - teach first, and then move on to another career. According to the DfE (2011b), if you learn to teach with Teach First, you are five times more likely to leave teaching than if you trained via the one-year PGCE route.

An 2017 Ipsos MORI poll for the Sutton Trust found that 48 per cent of 11-16-year-olds in London had received some form of private tuition at some point in their education, and that less well-off students were significantly less likely to be part of this group. The Sutton Trust advocates a means-tested voucher scheme for disadvantaged students to enable them to have access to tuition, as well as a fund for highly able students from such groups to enable them to maximize their potential 'in order to tackle the damaging effect private tuition has in reinforcing educational inequalities and holding back social mobility' (Jerrim, 2017: 29). In addition to a focus on the quality of education, there would be funding to facilitate the identification and reporting of those schools that push young people who might achieve less well out of their schools by 'off-rolling'. Off-rolling predominantly effects secondary schools, and is defined by Ofsted (2018b: 50) as 'when the removal is primarily in the interests of the school rather than in the best interests of the pupil'. Off-rolling is clandestine in that it is not a formal, permanent exclusion, and parents are often coerced into agreeing to it.

There are more instances of off-rolling in London than in any other part of the country (Ofsted, 2018b). Ofsted should be scrutinizing school rolls to detect off-rolling and make it explicit in its reporting of the statistics, fully cognizant, of course, that sometimes being taken off roll can be in the student's best interest, if the school has exhausted its strategies to support the student and alternative provision is the best way forward. Ofsted's 2017/18 Annual Report (2018b) highlights a concern about the continuing trend of a rise in the number of exclusions of students with special educational needs and/or disabilities (SEND), and how there is too much variance in the quality of education, health and care plans (EHC).

This mission to create greater equality and improved social mobility is hampered by the lack of homogeneity in schools, particularly in the secondary state sector, which comprises a bewildering range of schools within the maintained sector, all competing in the marketplace created by neo-liberalism. The genesis of this neo-liberalism in education is often blamed on Conservative Government policy up until 1997, but Tomlinson (2005: 91) makes the point that the Labour Government elected in that year accepted the 'Conservative faith in choice and competition, with education developing as a market commodity'. According to Wilby (2006), Tony Blair and his New Labour ministers were fully cognizant that it was their middle-class voters who would be able to capitalize most in the education marketplace. The current neo-liberal landscape presents complexity for parents, as well as encouraging morally feral practices, such as off-rolling students.

\section{Challenge five: The jungle - the range of schools}

It was the Labour Government which, in 2000, introduced academization as a way of trying to improve the academic achievements of students in socially disadvantaged 
areas. The 'fragmentation of the schools system can in part be traced back' to this (Hayes et al., 2018: 491). The Conservative-Liberal Democrat Coalition Government of 2010-15, through the Academies Act 2010, allowed local authority schools to convert to academy status as a way of gaining greater autonomy for their schools. Multi-Academy Trusts (MATs), comprising more than one school working together, were created 'to be the best opportunity to close the gaps between the best and weakest performing schools in the system' (DfE, 2016: 5). Some of these MATs have evolved organically by consensus, with converter academies; but some schools have been 'taken over' as sponsored academies, by one of the large academy chains, such as Harris and Ark. A main remedy for consistently failing schools is to place them in the hands of an academy trust chain: a process of quasi-privatization. There is nothing democratic in the process of handing a failing school over to an academy trust. MATs are not exposed to the same level of scrutiny and accountability as other schools. One of the justifications for the academization programme was that it would improve the educational achievement of students who were from disadvantaged backgrounds, but the reality would now seem to make this spurious in the light of research from Hutchings and Francis (2018) for the Sutton Trust, which found that two-thirds of children in MATs who are from disadvantaged backgrounds, as indicated by pupil premium (PP), perform below the national average for disadvantaged students.

The 1997-2002 Labour Government prohibited the opening of any more grammar schools in 1998 with the School Standards and Framework Act. There are currently 163 grammar schools in England, and the South-East is the region with the highest proportion of secondary school students attending them (12 per cent), with the SouthWest being the second highest (6 per cent) (Bolton, 2017). The Conservative Party (2015) general election manifesto pledged to remove the ban on the opening of new grammar schools, but the Conservatives lost their overall majority in the snap general election two years later, and the plan to open new grammar schools had to be placed on hold, with the pro-grammar school lobby placated by the allocation of additional funds for the expansion of grammar schools. Many in the Conservative Party yearn for the political opportunity to allow for the rapid expansion of grammar schools, arguing that they aid social mobility and produce better examination results. However, a report by Gorard and Siddiqui (cited in Benn, 2018: 141) on the data of every cohort of students in 2015 reported that there was 'no evidence base for a policy of increasing selection' and that 'the UK government should consider phasing the existing selective schools out'. The pro-grammar school lobby ignores such reports and the lack of evidence that grammar schools promote social mobility. For example, they are myopic about such evidence as an analysis by Foster et al. (2018), which found that some of the 16 grammar schools that have won a share of the government's $f 50$ million expansion fund to create more grammar school places have very poor records of admitting students from disadvantaged backgrounds. While only a few of the London boroughs still have grammar schools, these schools do not have catchment areas in the way that most non-selective schools do. Given the relative ease of transport within the capital, this means that students in non-selective boroughs can travel to grammar schools in other boroughs. Grammar school education is expanding with the 150 million allocated, but the election of a majority Conservative Government in 2020, or before, could see the opening of new grammar schools. Comprehensive education in London has this possible challenge, as do other parts of England that still have grammar schools.

The idea of a National Education Service (NES), on the lines of the National Health Service (NHS), was a central component of the Labour Party's (2017: n.p.) manifesto, and it looked to unify the disparate nature of the present education system 
in England, with 'a move to cradle-to-grave learning that is free at the point of use'. This NES would see 'moral capital, of which trust is an intrinsic part' as 'an essential component of building a collaboration of schools that achieves its moral purpose of providing the best education it can, especially for disadvantaged students' (Berwick and John, 2017: 210).

An NES also has the potential to address what some regard as a key issue in London and English schools: with the demise of the local authorities, there is an incoherent middle tier linking schools with central government. The current middle tier comprises remnants of local authorities, plus the DfE, MATs, RSCs, EFSA and so on, and is 'dysfunctional and bedevilled by a lack of trust between ministers, local authorities and many school leaders' (Hill, 2012: 6). If you are not a failing school, to whom do you turn for support in your improvement journey? A Parliamentary Accounts Committee Report (House of Commons Committee of Public Accounts, 2018b: n.p.) referred to the current system being 'fragmented and incoherent, leading to inefficiency for government and confusion for schools'. The demise of local authorities has intensified the development of the local context as competitive marketplaces for schools. A meso-study by Coldron et al. (2014) looked at the effects of schools moving out of local authority control and becoming academies. The head teachers interviewed thought that there was an inevitability 'that the weak would get weaker and the strong would get stronger' as 'the increasingly competitive local fields are creating winners and losers' (ibid.: 399). The National College for School Leadership (2012: 3) reports that while 'some schools gain significantly from the enhanced continuing professional development, the sharing of expertise and peer evaluation and challenge that comes from working with other schools ... others become increasingly isolated'. This is an emerging educational apartheid, with schools being 'left behind, or disenfranchised' (Earley and Greany, 2013: 226). These 'losers' are not part of the mainstream 'selfimproving school' movement. This bipartite system, where some schools are winners and some are losers, has a possible antidote in the form of an NES.

The lodestar for London's and England's schools over the next decade should be a commitment that all students receive an education that represents what Berwick and John (2017: 210) call 'the wisdom of global education'. A pursuance of this moral imperative might induce the antithesis of the current inequalities.

\section{Conclusions}

This article has highlighted what the author considers to be five main challenges facing London and English schools. All of them will require strong leadership on the macro-level of government, but also on the micro-level of the schools themselves. The latter will not be easy: there is the challenge of 'how to locate, develop and sustain committed and talented leadership' (Harris, 2008: 3). Ofsted (2018b: 14) reports on how 'leadership capacity in the school sector is worryingly thin' and, while acknowledging the continuation in the growth of systems leaders, how 'we need many more outstanding schools and school leaders to step up to the challenge of providing system leadership' (ibid.). The demands of school leadership are far more complex than they were at the turn of the century. There is therefore a need for a greater exploration of networking as part of a wider systems leadership agenda: 'the importance of working in teams, sharing responsibilities and working smarter will become even more important over the next decade' (Earley and Greany, 2017: 224). There is a clear capacity issue here, with the danger that system leaders could risk the continuing success of their existing school, or schools, by taking on others in difficulty. 
To make the proposition more attractive might involve more generous financial remuneration, but that does not address the stress and capacity issues. These can only really be alleviated by additional administrative support and an intensive central government strategy to develop the career flow of middle leaders into traditional senior roles, and then into systems leadership. We need to 'nurture, grow and develop broad-based leadership in our schools' (Harris, 2008: 3).

Distributed leadership has three levels: superficial, where the leadership is delegated, mostly though teaching and learning responsibility (TLR) payments; subterranean, mostly through the creation of new teams, with new roles and responsibilities; and deep, where leadership permeates the institution and is a part of its DNA (ibid.). The challenge is to develop deep distributed leadership, if the leadership crisis is to be addressed and the school leadership demands of 2030 met. One of the vanguards in developing future leaders is Teach First (2019d), which has, as part of its mission, a commitment to develop 'a pipeline of leaders' to address inequalities in schools. There is much in their ideology and practice that needs to be emulated more widely, but, as discussed earlier, there are issues with Teach First's rates of retention.

Some of the challenges facing schools in London and England on their journey to 2030 are problems that could be from any decade in recent history: a shortage of teachers, the curriculum in a state of flux, the lack of social mobility and a lack of appropriate funding. A relatively new challenge is the number of young people in schools who have mental health problems. Also, all of the attempts to address and resolve the challenges could be jeopardized by the uncertainties surrounding Brexit, and whether the result will be increased spending on education through fiscal flourish or the antithesis as a by-product of economic contraction.

A widely based, unequivocal moral commitment to produce the very best schooling, based on collaboration and a consensual road map drawn up by teachers and government - as well as other stakeholders - will be essential to minimize buffeting by the economy or the prejudices of vested interests. Too often, vast amounts of public money have been spent on seductive snake oils. A cultural shift is required in schools to avoid falling for such transient fads. Policy should be based on hard evidence of effectiveness. A clear master plan, whether solely for London or for England as a whole, would screen out potential distractions and anchor the mission to pragmatism and consistency, guided by a strident moral purpose: to create an education system that is more equitable and values the gifts and potential of every student. The country cannot afford to continue to tolerate the achievement gap and limits to social mobility in a system that systematically under-educates students - particularly in the possible 'Wild West' of Brexit.

Conservative party policy in the next general election manifesto may include a commitment to permit the opening of new grammar schools, thereby threatening the whole notion of comprehensive schooling in London. Antithetically, a radical, left-wing Labour manifesto might pledge the unification of the system, along the line of Benn's (2018) NES. The fact that the maximum period of time that can elapse between general elections is five years means that there could be at least two changes in the political parties in power between now and 2030, and dramatic oscillations in education policy. The Brexit deadlock has shown the difficulties in achieving a consensus in the UK Parliament, but such a unity would be essential if a meaningful and impactful long-term education master plan was to be drawn up and implemented. The challenges faced by the education system are such that they do not need the obstacles and interference of the vagaries of inter-party politics. 
Whatever education policy route is followed over the next decade will be within the context of government departments competing for funding. We have an increasingly elderly population, and their needs will place a strain on the welfare system. It may be that a political party has to be honest and state that schools will only be able to meet the challenges and thrive if there is an identifiable increase in taxation - perhaps even called the 'Education Tax'.

\section{Notes on the contributor}

David Parry was the head teacher of a large London comprehensive school and has taught for 40 years. He has a personal commitment to lifelong learning, gaining an MBA in Educational Leadership (international) at UCL Institute of Education in 2015. He has just successfully completed an MA in History of Education, also at UCL Institute of Education. His dissertation for the latter was on Michael Duane and Risinghill School (1960-5). Dr Parry works as a researcher and an education consultant.

\section{References}

Adonis, A. (2014) 'My vision for London in 2030'. The Independent, 4 April. Online. https://tinyurl. com/ybru93nf (accessed 19 April 2019).

Astle, J. (2017) The Ideal School Exhibition. London: RSA.

Ball, S.J. (2003) 'The teacher's soul and the terrors of performativity'. Journal of Education Policy, 18 (2), 215-28.

Barton, G. (2018) 'Divergent pathways'. Leader, 106, 4-5.

Benn, M. (2018) Life Lessons: The case for a national education service. London: Verso.

Berwick, G. and John, S. (2017) 'School networks, peer accountability and the brokerage of knowledge and expertise'. In Earley, P. and Greany, T. (eds) School Leadership and Education System Reform. London: Bloomsbury Academic, 198-210.

Blanden, J., Greaves, E., Gregg, P., Macmillan, L. and Sibieta, L. (2015) Understanding the Improved Performance of Disadvantaged Pupils in London (Social Policy in a Cold Climate Working Paper 21). London: Centre for Analysis of Social Exclusion. Online. http://sticerd.lse.ac.uk/dps/case/ spcc/wp21.pdf (accessed 11 January 2019).

Bolton, P. (2017) Grammar School Statistics (House of Commons Library Briefing Paper 1398). London: House of Commons Library.

Brighouse, T. (2015) 'Local authorities and the London Challenge'. In Brighouse, T., Coles, J., Gilbert, C., Lewis, E., Cooper, B., Pipe, J., Quirk, B. and Robinson, P. Lessons from London: Insights on improving schools. London: London Councils, 4-10. Online. https://tinyurl.com/ yyob5x44 (accessed 20 April 2019).

Bubb, S. and Earley, P. (2013) 'The use of training days: Finding time for teachers' professional development'. Educational Research, 55 (3), 236-48.

Burgess, S. (2014) Understanding the Success of London's Schools (Working Paper 14/333). Bristol: Centre for Market and Public Organisation. Online. https://tinyurl.com/yyrdcts3 (accessed 20 April 2019).

Busson, S. (2018) Exploring the Future of Education: A journey through Europe's education innovations. Paris: SMP.

Coldron, J., Crawford, M., Jones, S. and Simkins, T. (2014) 'The restructuring of schooling in England: The responses of well-positioned headteachers'. Educational Management Administration and Leadership, 42 (3), 387-403.

Collins, J. (2001) Good to Great: Why some companies make the leap... and others don't. London: Random House Business Books.

Conservative Party (2015) 'The Conservative Party manifesto 2015'. Online. www.conservatives.com/ manifesto2015 (accessed 10 January 2019).

DfE (Department for Education) (2011a) 'School discipline: New guidance for teachers'. Press release, 11 July. Online. https://tinyurl.com/y2n5w7qz (accessed 20 April 2019).

DfE (Department for Education) (2011b) A Profile of Teachers in England from the 2010 School Workforce Census (Research Report DFE-RR151). London: Department for Education. Online. https://tinyurl.com/yxg93e43 (accessed 20 April 2019). 
DfE (Department for Education) (2016) Multi-Academy Trusts: Good practice guidance and expectations for growth. London: Department for Education. Online. https://tinyurl.com/ y8umxxj4 (accessed 20 April 2019).

DfE (Department for Education) (2018a) Mental Health and Behaviour in Schools. London: Department for Education. Online. https://tinyurl.com/y7nypo2f (accessed 20 April 2019).

DfE (Department for Education) (2018b) National curriculum assessments at Key Stage 2 in England, 2018 (provisional). Online. https://tinyurl.com/y32jdcn9 (accessed 4 May 2019).

DfE (Department for Education) (2019a) English Baccalaureate (EBacc). Online. https://tinyurl.com/ ps8vjuk (accessed 5 May 2019).

DfE (Department for Education) (2019b) Introduction of T levels. Online. https://tinyurl.com/ y62nmatl (accessed 5 May 2019).

DfE (Department for Education) (2019c) Teacher Recruitment and Retention Strategy. London: Department for Education. Online. https://tinyurl.com/y2c7ma2q (accessed 20 April 2019).

DfE (Department for Education) (2019d) Teacher recruitment and retention strategy: One-page summary for schools. Online. https://tinyurl.com/yyjoxdss (accessed 20 April 2019).

Earley, P. and Greany, T. (2017) 'Postscript: The future of leadership'. In Earley, P. and Greany, T. (eds) School Leadership and Education System Reform. London: Bloomsbury Academic, 222-8.

Edtech UK (2015) Edtech: London capital for learning technology. London: Education Foundation. Online. https://tinyurl.com/y6y8ogbf (accessed 20 April 2019).

Foster, D., Long, R. and Roberts, N. (2018) Grammar Schools in England (House of Commons Library Briefing Paper SN07070). London: House of Commons Library.

Ghuman, J. (2018) 'Looking into the London Challenge'. Sutton Trust News, 7 February. Online. https://tinyurl.com/yy8ow6hp (accessed 21 April 2019).

Godfrey, D. (2016) 'Leadership of schools as research-led organisations in the English educational environment: Cultivating a research-engaged school culture'. Educational Management Administration and Leadership, 44 (2), 301-21.

Greany, T. (2017) 'Collaboration, partnerships and system leadership across schools'. In Earley, P. and Greany, T. (eds) School Leadership and Education System Reform. London: Bloomsbury Academic, 56-65.

Harris, A. (2008) Distributed School Leadership: Developing tomorrow's leaders. London: Routledge.

Hayes, S., Jopling, M. and Gul, R. (2018) 'What have the changes made to primary and secondary assessment frameworks since 2014 done to the "London effect" in school performance?'. London Review of Education, 16 (3), 491-506.

Hill, R. (2012) The Missing Middle: The case for school commissioners: Developing a system of great schools in England. London: RSA. Online. https://tinyurl.com/y45dccr8 (accessed 20 April 2019).

Hinds, D. (2018) '2018 speech at Association of School and College Leaders' Conference'. Online. www.ukpol.co.uk/damian-hinds-2018-speech-at-association-of-school-and-college-leadersconference/ (accessed 5 May 2019).

House of Commons Committee of Public Accounts (2018a) Retaining and Developing the Teaching Workforce: Seventeenth Report of Session 2017-19. London: House of Commons.

House of Commons Committee of Public Accounts (2018b) Converting schools to academies: Conclusions and recommendations. Online. https://tinyurl.com/y2o $7 \mathrm{kwfd}$ (accessed 21 April 2019).

Husbands, C. (2014) 'Lessons from London: What does the London Challenge tell us about school improvement and reform?'. In Woods, D. and Brighouse, T. (eds) The Story of London Challenge. London: London Leadership Strategy, 142-7.

Hutchings, M. and Francis, B. (2018) Chain Effects 2018: The impact of academy chains on lowincome pupils. London: Sutton Trust. Online. https://tinyurl.com/yyw5jttu (accessed 5 May 2019).

Jerrim, J. (2017) Extra Time: Private tuition and out-of-school study, new international evidence. London: Sutton Trust. Online. https://tinyurl.com/y55ff45x (accessed 21 April 2019).

Kidson, M. and Norris, E. (2014) Implementing the London Challenge. York: Joseph Rowntree Foundation. Online. https://tinyurl.com/yxj5ewet (accessed 21 April 2019).

Labour Party (2017) 'Manifesto: Towards a national education service'. Online. https://labour.org.uk/ manifesto/education (accessed 3 January 2019).

Liebreich, M. (2016) 'An environment fit for Londoners'. In Shorthouse, R. and Booth-Smith, L. (eds) The Future of London: 2050. London: Bright Blue Campaign and Localis, 42-5. Online. https://tinyurl.com/y5nxanf5 (accessed 21 April 2019).

LLS (London Leadership Strategy). (2018) 'The London Leadership Strategy'. Online. www.londonleadershipstrategy.com (accessed 6 December 2018). 
Londonair (2018) 'Air pollution'. Online. www.londonair.org.uk (accessed 17 December 2018).

National College for School Leadership (2012) School Leadership for a Self-Improving System. Online. https://tinyurl.com/y4kamwn2 (accessed 3 May 2019).

Ofsted (2018a) 'Chief Inspector sets out vision for new Education Inspection Framework'. Press release, 11 October. Online. https://tinyurl.com/y7fcc98s (accessed 21 April 2019).

Ofsted (2018b) The Annual Report of Her Majesty's Chief Inspector of Education, Children's Services and Skills 2017/18. London: Ofsted. Online. https://tinyurl.com/y89d99wh (accessed 21 April 2019).

Parry, D. (2011) 'How Important are Target Grades and Internal Tracking Systems in Improving the Academic Achievement of Sixth Form Students?'. Unpublished PhD thesis, Institute of Education, University of London.

Policy Institute at King's (2017) Economic and Demographic Scenarios for London in 2030. Cambridge: Cambridge Econometrics and SQW. Online. https://tinyurl.com/y3zbw6nk (accessed 20 April 2019).

Population UK (2019) 'London Population 2019'. Online. www.ukpopulation.org/london-population (accessed 5 May 2019).

Precey, R. (2012) 'Leadership and trust in education: The often missing magic glue'. Zarządzanie Publiczne, 4 (20), 9-17. Online. http://citeseerx.ist.psu.edu/viewdoc/download?doi=10.1.1.898.32 24\&rep=rep1\&type=pdf (accessed 3 May 2019).

Rogers, T. (2016) 'A teacher's vision of education in the year 2030'. Times Educational Supplement, 16 December. Online. www.tes.com/news/teachers-vision-education-year-2030 (accessed 10 December 2018).

Royal Society and British Academy (2018) Harnessing Educational Research. London: Royal Society and British Academy. Online. https://tinyurl.com/yxkjuyxb (accessed 21 April 2019).

Smartrail World (2015) 'London's population will be $10 \mathrm{~m}$ by 2030 , how will public transport cope?' Online. www.smartrailworld.com/how-london-transport-is-planning-to-cope-with-a-populationof-10m-by-2030 (accessed 5 May 2019).

Spielman, A. (2018) Speech to the SCHOOLS NorthEast Summit, 11 October. Online. https://tinyurl. com/y5d7xwh7 (accessed 21 April 2019).

Teach First (2019a) 'Empowering people to make education fair'. Online. www.teachfirst.org.uk/ourmission/what-we-do (accessed 2 May 2019).

Teach First (2019b) 'Equality through education'. Online. www.teachfirst.org.uk/our-mission (accessed 2 May 2019).

Teach First (2019c) 'Income defines how well children do at school'. Online. www.teachfirst.org.uk/ our-mission/the-issue (accessed 2 May 2019).

Teach First (2019d) 'Our impact on the lives of the UK's poorest children'. Online. www.teachfirst. org.uk/our-mission/our-impact (accessed 2 May 2019).

Tomlinson, S. (2005) Education in a Post-Welfare Society. 2nd ed. Maidenhead: Open University Press.

UK Government (2015) '2010-2015 government policy: Teaching and school leadership'. Online. www.gov.uk/government/publications/2010-to-2015-government-policy-teaching-and-schoolleadership (accessed 5 May 2019).

UK Parliament (2010) 'Academies Act 2010'. Online. www.legislation.gov.uk/ukpga/2010/32/ contents (accessed 19 April 2019).

Wilby, P. (2006) 'A delay on the road to meritocracy'. In Dench, G. (ed.) The Rise and Rise of Meritocracy. Oxford: Blackwell Publishing, 214-20.

Williams, J. (2018) 'It Just Grinds You Down': Persistent disruptive behaviour in schools and what can be done about it. London: Policy Exchange. Online. https://tinyurl.com/y5l5bf2m (accessed 20 April 2019).

Woods, D. (2014) 'The London school'. In Woods, D. and Brighouse, T. (eds) The Story of London Challenge. London: London Leadership Strategy, 32-49.

Woods, D. and Brighouse, T. (2014) 'The legacy of the London Challenge'. In Woods, D. and Brighouse, T. (eds) The Story of London Challenge. London: London Leadership Strategy, 132-41.

Woods, D. and Macfarlane, R. (2017) 'What makes a great school in the twenty-first century?'. In Earley, P. and Greany, T. (eds) School Leadership and Education System Reform. London: Bloomsbury Academic, 79-89. 